\title{
NeMZeTKöZIESÍTÉS A MESTERKÉPZÉSBEN
}

\author{
ERDEI LUCA ALEXA
}

\author{
ELTE Neveléstudományi Doktori Iskola \\ ELTE Neveléstudományi Intézet
}

A nemzetközi együttműködésben megvalósuló közös képzési programok a határokon átnyúló együttműködések jó gyakorlatai, így a tanulási-tanítási célú mobilitás kiemelt serkentői is egyben, melyek nem csupán az intézményi stratégiákban, de a nemzeti és regionális szakpolitikákban is fontos szerepet kapnak. Erre építve kutatásunkban a joint degree programok megvalósítását ösztönző regionális, nemzeti és intézményi szakpolitikai dokumentumok, stratégiák, koncepciók összehasonlító jellegű megismerésére vállalkoztunk. Jelen kutatási összefoglaló a közös képzéseket érintő európai uniós és latin-amerikai regionális szintủ célkitüzések, illetve támogatási programok vizsgálatának eredményeit tartalmazza. ${ }^{1}$

Kulcsszavakः nemzetköziesítés, közös képzés, regionális együttmüködés

The international joint degree programs can be defined as good practices of cross-border cooperation, therefore they serve as key incentives for learning and teaching mobility, which are important not only in institutional strategies but also in national and regional policies. Based on the aforementioned approach, our research aims to compare the regional, national and institutional policy documents, strategies and concepts that encourage and support the implementation of joint degree programs. The following research report summerizes the results of EU and Latin American regional objectives and implementation programs related to joint degree programs.

Keywords internationalisation, joint degree, regional cooperation

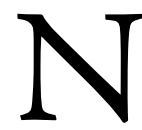
apjaink folyamatosan változó környezetében a felsőoktatási rendszerek komplex világa, így a felsőoktatás nemzetköziesítésének témája egyre fokozódó érdeklődésre tart számot a gyakorlati szakemberek és a kutatói közösségek körében egyaránt. A nemzetköziesítés gyakorlatának felértékelödését jelzi többek között, hogy számos nemzetközi szervezet, szakmai hálózat (pl.

Levelező szerző: Erdei Luca Alexa, ELTE PPK Neveléstudományi Intézet, 1075 Budapest, Kazinczy u. 23-27.4. em. 403. E-mail: pap.luci@gmail.com

1 A tanulmány az Emberi Erőforrások Minisztériuma ÚNKP-I7-3 Kódszámú Új Nemzeti KiválóSÁg Programjának támogatásával készült. 
az OECD Institutional Management in Higher Education networkje) segíti közös nemzetköziesítési stratégiák kidolgozását, a felsőoktatási intézmények nemzetközi agendájának megvalósítását és értékelését, miközben a nemzetköziesítéshez kapcsolódó indikátorok szerepe, jelentősége megnövekedett a felsőoktatási rangsorokban (Delgado-Marquez-Hurtado-Torres-Bondar 2011). Mindez hozzájárult a nemzetköziesítés jelenségének mint kutatási problémának az előtérbe kerüléséhez is, amit jól mutat a felsőoktatás nemzetköziesitése kulcsszóval megjelölt publikációk számának folyamatos növekedése (pl. az EBSCO folyóiratkeresőben megtalálható, 2000 óta megjelent több mint 800 tudományos igényű publikáció), illetve a témára fokuszáló tudományos folyóiratok (pl. International Higher Education) működése is (Kovács-Taróssy-Kovács 2015; Kebm-Teichler 2007).

A téma kutatási jellegű feltárásakor az egyik első nehézséget az adja, hogy hogyan értelmezzük és ragadjuk meg a felsőoktatás nemzetköziesítésének összetett jelenségvilágát. Knight (2003a: 2) megfogalmazásában ez „egy olyan folyamat, amelynek során a felsőoktatás céljaiba, funkcióiba és a megvalósítást szolgáló tevékenységekbe integrálásra kerül egy nemzetközi, interkulturális vagy globális dimenzió”. A nemzetköziesítés jelenségeinek vizsgálatakor számos perspektívájából közelíthetünk a téma felé, amelyek közül kutatásunkban az alábbi keretrendszert alkalmazzuk: az egyik irányt a felsőoktatási rendszerek és intézmények saját oktatási-kutatási tevékenységének nemzetközi, interkulturális dimenzióval való bővítése jelenti, mely egyfajta befelé irányuló fejlődéstfejlesztést feltételez (internationalisation at home), míg a másik irányt a határokon átlépő oktatás-kutatás koncepciója adja (cross-border education, internationalisation abroad), amelyben a hangsúly a személyek, programok, esetleg intézmények határokon átnyúló együttmüködésén, mobilitásán van, s ilyen módon kifelé irányuló tevékenységeket ölel fel (Kinght 2003a, 2003b, 2004; de Wit et al. 2015; OECD 2004). E két megközelítés azonban nem választható el egymástól élesen, mindkettő a nemzetköziesítés átfogó koncepciójának részeként értelmezhető (Knight 2008; Tham-Kam 2008).

A kifelé irányuló nemzetköziesedés legjellemzőbb megvalósulási formái a következők (Knight 2004; de Wit et al. 2015):

- Kimenő egyéni mobilitás: a felsőoktatás különböző szintjein lévő hallgatók mobilitása kreditszerzési céllal, illetve oktatói, kutatói és adminisztratív munkatársak szakmai fejlődési célú mobilitása.

- Képzési programok mobilitása: teljes képzés elvégzésével diplomaszerzés külföldön.

- Intézmények mobilitása: olyan kihelyezett képzések, ahol a hallgató más országban teljesíti a követelményeket, mint ahol a kreditet biztosító intézmény található (pl. branch-campusok).

A befelé irányuló nemzetköziesedés legjellemzőbb megvalósulási formái (Knight 2004; de Wit et al. 2015):

- A kurrikulum nemzetköziesedése

- A tanulási és tanítási folyamatok nemzetközi dimenziójának erősödése

- Bejövő egyéni mobilitás

- A kutatás nemzetköziesítése

$\mathrm{A} z$ angol nyelvü keresésben az internationalisation and/of higher education kifejezéseket alkalmaztuk. 
Ebben a keretrendszerben különleges helyet foglalnak el a nemzetközi együttmüködésben megvalósuló közös mesterképzési programok, mivel azok mindkét megközelítésből értelmezhetők. Jelen kutatásban nemzetközi együttmüködésben megvalósuló közös képzési programok (joint degree) alatt olyan kettő vagy több partnerország akkreditált felsőoktatási intézménye által létrehozott képzést értünk, amely konzorciumi együttműködés keretében valósul meg, integrált kurrikulumot és esetleg kutatási tevékenységet foglal magában, s központi szerephez jut benne a hallgatók által megszerzett kreditek kölcsönös elismerése. A programok további fontos eleme a mobilitás, így a hallgatók általában két vagy több partnerintézményben tanulnak, majd a program sikeres elvégzése esetén közös diplomát vagy diplomamellékletet kapnak (Obst-Kuder-Banks 2011; Knight 2008, 2011; Michael-Balraj 2003). Az első megközelítés szerint a közös képzési forma interpretálható úgy, mint egy régió vagy ország felsőoktatási versenyképességét ösztönző, vonzerejét növelő képzési forma, illetve az ilyen programot megvalósító intézmények saját képzési palettájának szélesítését, az intézmény belső kurrikulumfejlesztési tevékenységét segítő nemzetköziesítési törekvés, amely sok esetben bejövő mobilitással is párosul. Ezzel szemben áll az a megközelítés, miszerint az adott felsőoktatási rendszer kifelé, más országok irányába történő terjeszkedésének zászlóshajói a közös képzési programok, míg az egyes felsőoktatási intézmények szintjén a már meglévő képzések, kurrikulumok más intézmények felé történő közvetítéseként jelenhetnek meg, amely általában kifelé irányuló hallgatói és oktatói mobilitással is együtt jár (Knight 2003a, 20036, 2004, 2012; OECD 2004; de Wit et al. 2015).

Fontos megemlíteni, hogy a felsőoktatási nemzetköziesítés jelenségeinek a vizsgálata jellemzően az alábbi tematikus fókuszok köré szerveződik, mely témák jól mintázzák az oktatáskutatás tartalmi orientációinak sokféleségét (Halász 2013): 1) oktatói és hallgatói mobilitás, 2) a felsőoktatási rendszerek kölcsönös egymásra hatása, 3) a tanulás-tanítás-kutatás világának nemzetköziesedése, 4) a nemzetköziesítési stratégiák vizsgálata, összehasonlítása, 5) a felsőoktatási tudástranszfer témája, 6) az együttműködési módok és versenyelőnyök feltérképezése, illetve 7) a nemzeti és szubnacionális szakpolitikák nemzetköziesedést feltáró elemzése (Kebm-Teichler 2007; Yemini-Sagie 2016). A közös képzések jól vizsgálhatók a fent említett tematikus fókuszokhoz kapcsolva, mivel a határokon átnyúló, képzési célú együttműködések jó gyakorlatai, így a tanulási-tanítási célú mobilitás kiemelt ösztönzői is egyben, melyek nem csupán az intézményi stratégiákban, de a nemzeti és regionális szakpolitikákban is fontos szerepet kapnak (Aerden-Braathen-Frederiks 2010; Knight 2008, 2011; Nickel-ZdebelWesterbeijden 2009; Obst et al. 2011).

A fenti keretrendszert és a bemutatott tematikus fókuszokat felhasználva kutatásunkban arra keressük a választ, hogy milyen jellemzőik és támogatottságuk van, illetve milyen szerepet töltenek be a nemzetközi együttmüködésben megvalósuló közös mesterképzési programok a regionális, nemzeti és intézményi szintű nemzetköziesítési törekvésekben, s az egyes szinteken a befelé vagy a kifelé irányuló nemzetközi tevékenységek profiljába illeszkednek-e inkább (Obst et al. 2011; Knight 2008, 2011; MichaelBalraj 2003). Átfogó szakirodalmi elemzés, illetve a témában megjelent empirikus kutatások eredményeinek másodelemzése után három szinten valósítottuk meg kutatásunkat. A makroszintű kutatási szakaszban a felsőoktatás nemzetköziesítéséhez kapcsolódó európai uniós és latin-amerikai szakpolitikai és stratégiai célkitűzéseket elemeztük. Választásunkat alátámasztotta a közös képzések szerepének felerősödése 
és növekvő számú megjelenése mind az európai uniós, mind a latin-amerikai régióban (Egron-Polak-Hudson 2014; Gacel-Ávila 2009).

Kutatásunk mezoszintjén a kutatásba bevont országok felsőoktatási rendszereiben tekintettük át és hasonlítottuk össze a közös képzési programokat támogató szakpolitikai és gyakorlati jellegü kezdeményezéseket, a dokumentumelemzés és a félig strukturált interjú módszerével (Varga 2014; EUA 2015; Knight 2008). A latin-amerikai régió esetében célunk volt egy közép-és egy dél-amerikai ország kiválasztása, figyelembe véve az adott ország felsőoktatásának nemzetközi profiljáról elérhető szakirodalmak mennyiségét és minőségét, illetve az ország elérhetőségét, megközelíthetőségét és a kutatásunkhoz rendelkezésünkre álló forrásokat, amelyek elengedhetetlenek a mikroszintű kutatás lebonyolításához. Ezek alapján Ecuadorra és Mexikóra esett választásunk, ám jelen kutatás keretei között ez idáig csak az ecuadori adatfelvétel valósult meg. Az EU régiójában végzett vizsgálathoz Magyarország mellett a két szupranacionális régió közötti híd szerepére való tekintettel Spanyolország került bevonásra.

A kutatás legalsó, mikroszintjén a kutatásba bevont országok egy-egy kiválasztott felsőoktatási intézményében tártuk fel az intézmények által megvalósított közös képzési programok nemzetköziesítési agendában betöltött helyét, működésük jellemzőit és eredményeit a dokumentumelemzés, a félig strukturált interjú és a résztvevő megfigyelés módszereivel (Falus et al. 2011). Az intézmények kiválasztásában kiemelt szempont volt, hogy rendelkezzen az intézmény legalább egy olyan közös képzési programmal az elmúlt 5 évben, amelynek a megvalósításában aktívan részt vett, vagy vegyen részt jelenleg közös képzés tervezésében, fejlesztésében (beleértve a közös képzések esetében jellemző együttmúködő partner státuszt is). Jelen rövid kutatási beszámolóban mindazonáltal csak a makroszintű kutatás eredményeinek bemutatására vállalkozunk, a mezo- és a mikroszintű kutatási eredményeket egy nagyobb terjedelmű kutatási jelentésben ismertetjük.

A közös képzési programok regionális nemzetköziesítési folyamatokban betöltött helyének, szerepének értelmezésekor elsőként az Európai Unió kezdeményezéseit tekintettük át. Az Európai Unióban zajló nemzetköziesítési folyamatoknak meghatározó területét jelentik a Bologna reformhoz kötődő jelenségek, azon belül is a nemzetközi „joint degree” programok, melyek a határokon átnyúló együttmüködések és a kifelé irányuló hallgatói, illetve oktatói mobilitás ösztönzőiként fontos szerepet töltenek be a reform célkitüzéseinek megvalósításában (Aerden-Braathen-Frederiks 2010). Az uniós szakmai diskurzusokban túlnyomó részt mesterképzési szinten értelmezett nemzetközi közös képzési programokra nem csupán a Bologna-folyamat kapcsán, de az előfutárának tekinthető Sorbonne-i Nyilatkozatban is található utalás, melyek így az európai felsőoktatás harmonizációjának eszközeiként értelmezhetők (Varga 2014; EUA 2015). A közös képzések EU-szintű nemzetköziesítési folyamatokban betöltött meghatározó szerepét támasztja alá az Erasmus Mundus program múködése, mely program Knight (2008) szerint egyedülállóan komplex stratégiai célokkal, illetve forrástámogatással ösztönözte a közös képzések létrejöttét.

Az Európai Felsőoktatási Térség kiválóságának láthatóvá tételét megcélzó Erasmus Mundus programban megvalósult közös mesterképzések legalább három európai uniós program- és partnerország együttműködésében jöttek létre. A program követelményként támasztotta a konzorciumok elé, hogy egy új, közösen kialakított, integrált 
kurrikulumot és szükség esetén egy hozzá kapcsolódó tananyagbázist is létrehozzanak (Európai Bizottság 2014, 2015). A program 2003-2013 közötti müködése során megközelítőleg 300 közös mesterképzési program és mintegy 40-50 közös doktori képzés valósult meg (Blakemore-Burquel 2012). A 2014 óta az Erasmus+ program keretében müködő közös mesterszakok program (EMJMD) koncepciója az egyéni szakmai elömenetel támogatása mellett az alábbi stratégiai célokat is szolgálja:

- „a kiválóság, a minőségfejlesztés, az innováció és a nemzetköziesítés támogatása;

- az Európai Felsőoktatási Térség minőségének és vonzerejének növelése a világban és az EU külügyi tevékenységének támogatása a felsőoktatás terén;

- a mesterszakon végzett hallgatók kompetenciáinak és készségeinek javítása, különös tekintettel a munkaerőpiaci elhelyezkedés esélyeinek növelésére a munkáltatók bevonása révén" (Tempus Közalapitvány 2017).

Varga (2014) ezen túlmenően rámutatott, hogy „az Erasmus Mundus a bolognai folyamat egyik kulcskoncepciójának, a konvergenciának vált fontos eszközévé. $\mathrm{Az}$ EMMC-programok bevezetéséhez azért füztek nagy reményeket, mert alkalmasnak tüntek a különféle felsőoktatási rendszerek, intézmények, képzések és gyakorlatok közelítésére, azaz hozzájárulnak az Európai Felsőoktatási Térség további integrációjához" (Varga 2014: 19). Az európai uniós törekvések tehát egyrészt arra fókuszálnak, hogy a közös képzések a stratégiai partnerségeken alapulva segítsék a kifelé irányuló hallgatói, oktatói és programmobilitást, miközben egyértelműen az intézményfejlesztés, a tanulás-tanítási folyamatok és a kurrikulum nemzetköziesítésének eszközei is, így tehát mind az ,internationalisation at home”, mind a „cross-border education” koncepciók szempontjából jelentős szerepük van.

Szükséges még kiemelni a közös képzések uniós tendenciáinak vizsgálatával kapcsolatban, hogy az Unió már a kétezres évek elejétől, így többek között az Erasmus Mundus program kezdetétől nagy hangsúlyt fektetett rá, hogy a közös mesterképzések keretében intenzív együttműködés jöjjön létre a latin-amerikai és az európai uniós országok között (Európai Bizottság 2015), segítve ezzel a két szupranacionális régió együttműködését, felsőoktatási rendszereinek átláthatóságát. A két régió közötti nemzetközi együttműködést segítette továbbá az „EU Regional Cooperation with LA” támogatási program müködése is, amely a 28 EU-tagállam és 18 latin-amerikai ország együttmüködésével valósult meg. Ennek részeként 2007 és 2013 között müködött az ALFA projekt, ami az Erasmus Mundus program mellett segítette a közös képzések alapjául szolgáló partnerségek kialakítását, majd 2014 óta működik az Erasmus+ program, amelynek deklarált célja a nemzetközi kreditmobilitás és a kapacitásbővítés mellett az EU és a latin-amerikai régió közötti közös képzések létrehozásának segítése is.

A közös képzési programok számának és fontosságának növekedése nem csak az Európai Unióban jelentős; az IAU 2014-ben megjelent 4th Global Survey on Internationalization of Higher Education kiadványa szerint a felsőoktatási intézmények nemzetközi eredményességének három legfontosabb indikátora között szerepel a közös vagy kettős képzési programok indítása, aminek köszönhetően számottevően nőtt a megvalósított közös képzések száma is: a felmérésben részt vevő 1300 intézmény mintegy fele biztosított közös vagy kettős diplomalehetőséget a hallgatóinak (Egron-PolakHudson 2014). Ez a tendencia nem csupán az Európai Unióban, Észak-Amerikában és az ázsiai régióban, de Latin-Amerikában és a Karib-térségben is megfigyelhető. 
Gacel-Ávila (2009) empirikus felmérése szerint az elmúlt években jelentősen felértékelődött a latin-amerikai felsőoktatási diskurzusokban a közös képzések témája, mindazonáltal a közös képzések bevezetésének nincs olyan átfogó, regionális szintű koncepciója, mint amilyen az Európai Unió esetében az Erasmus Mundus program, így főként az intézményi szintű célok szintéziseként értelmezhetőek. A felmérés szerint a közös képzések a kurrikulum nemzetköziesítésének, innovatív programok elindításának és ezáltal az intézményfejlesztésnek az eszközeiként szolgálnak (Gacel-Ávila 2009; Knight 2011). Ez kiemelten fontos a latin-amerikai felsőoktatás szempontjából, mivel a World Bank és az OECD 2005-ös jelentése szerint a latin-amerikai felsőoktatási intézmények kurrikuluma meglehetősen kevés változáson ment keresztül az elmúlt évtizedek során, mely nem kedvez a nemzetközi törekvések térnyerésének. A nemzetközi dimenzió kurrikulumba építésének egyik legfőbb akadályát azonban a régió felsőoktatásának hagyományos, rugalmatlan és túlzottan diszciplináris alapokon szerveződő tantervi modellje adja (de Wit et al. 2005; Deardorff-de Wit-Heyl 2012).

Gacel-Ávila (2009) felhívja rá a figyelmet, hogy a latin-amerikai régióban jelentős különbséget lehet tenni a közös képzések bevezetésének intézményi céljai között annak figyelembevételével, hogy magánintézmény vagy állami felsőoktatási intézmény kívánja bevezetni a közös képzést. A magánkézben lévő felsőoktatási intézmények a saját presztízsük emelése, illetve az önköltséges hallgatók számának növelése céljából tartják fontosnak a közös képzési programok elindítását, míg az állami fenntartású intézmények a kapacitásbővítés és a posztgraduális képzések fejlesztésének lehetősége miatt tartják ideálisnak a közös képzések intézményi nemzetköziesítési agendában való megjelenését. A közös képzések latin-amerikai bevezetése tehát főként az „internationalisation at home" jellegü kezdeményezések támogatására jönnek létre.

Kutatásunk makroszintű elemzésének eredményeként elmondható, hogy a közös képzések jelentős, átfogó és egyedülálló szakpolitikai támogatást élveznek az európai uniós szakpolitikai diskurzusokban, s jelentős anyagi támogatást kaptak az Erasmus Mundus program 2003-as bevezetésétől kezdve. Az uniós támogatási sémák azonban nem csupán arra fokuszálnak, hogy a közös képzések az Unión belüli felsőoktatási intézmények befelé irányuló, kurrikulumfejlesztési, kapacitásbővítési és a tanulás-tanítási folyamatok innovációját segítő céllal jöjjenek létre, hanem az EU-n kívüli országokkal való együttmüködések, a kifelé irányuló egyéni és programmobilitások eszközeinek is tekinti a közös képzéseket. Ebben a megközelítésben tehát egyszerre az „internationalisation at home” és a „cross-border education” típusú tevékenységek közé sorolhatóak a közös képzési programok. Ezzel ellentétben a latin-amerikai régióban egyértelműen a befelé irányuló nemzetköziesítés eszközének tekintik a közös képzéseket, amelyek segítik a hagyományos felsőoktatási tradíciók lebontását, a kurrikulum innovációját, illetve a hallgatók intézménybe történő bevonzását.

\section{IRODALOM}

Aerden, A., Braathen, K. \& Frederiks, M. (2010) Joint programmes: Too many cooks in the kitchen? European Consortium for Accreditation. http://ecahe.eu/w/images/c/c0/ Eca-publication---joint-programmes-too-many-cooks-in-the-kitchen-final.pdf [Letöltve: 2018. 03. 10.] 
Blakemore, M. \& Burquel, N. (2012) EMQA - Erasmus Mundus Quality Assessment Handbook of excellence - Doctoral Programs. http://emqa.eu/Downloads/Handbook\%20 of\%20Excellence\%202012\%20-\%20Doctoral\%20-\%20Final.pdf [Letöltve: 2018. 03. 06.]

Deardorff, D. K., de Wit, H. \& Heyl, J. D. (2012) Bridges to the Future. The SAGE Handbook of International Higher Education. pp. 457-485.

Delgado-Marquez, B. L., Hurtado-Torres, N. E. \& Bondar, Y. (2011) Internationalization of Higher Education: Theoretical and Empirical Investigation of Its Influence on University Institution Rankings. Revista de Universidad y Sociedad del Conocimiento (RUSC), Vol. 8. No. 2. pp. 265-284.

DE WIT, H. (2002) Internationalization of Higher Education in the United States of America and Europe: A Historical, Comparative, and Conceptual Analysis. Westport, CT, Greenwood Press.

de Wit, H., Hunter, F., Howard, L. \& Egron-Polak, E. (2015) Internationalisation of Higher Education. Brüsszel, Európai Parlament. http://www.europarl.europa.eu/ RegData/etudes/STUD/2015/540370/IPOL_STU(2015)540370_EN.pdf [Letöltve: 2018. 01. 20.]

de Wit, H., Jaramillo, I. C., Gacel-Ávila, J. \& Knight, J. (2005) Higher Education in Latin America: The International Dimension. Washington, World Bank.

Egron-Polak, E. \& Hudson, R. (2014) IAU 4th Global Survey on Internationalization of Higher Education. Párizs, International Association of Universities.

EUA (2015) The European Higher Education Areain 2015: Bologna Process Implementation Report. Brüsszel, EUA.

Európai Bizottság (2014) Erasmus+ Programme Guide. Brüsszel, Európai Bizottság. http:// ec.europa.eu/programmes/erasmus-plus/sites/erasmusplus/files/files/resources/erasmusplus-programme-guide_en.pdf [Letöltve: 2018. 02. 23.]

Európai Bizottság (2015) Factsheet 'Regional Cooperation with Latin America: Promotion of Higher Education'. Brüsszel, Európai Bizottság. https://ec.europa.eu/europeaid/sites/ devco/files/lac-factsheet-en-web-150413-final.pdf [Letöltve: 2018. 02. 25.]

Falus I., Tóth Istvánné Környei M., Bábosik I., Réthy Endréné, Szabolcs É., Nahalka I., Csapó B. \& Mayer Miklósné Nádasi M. (2011) Bevezetés a pedagógiai kutatás módszereibe. Budapest, Müszaki Könyvkiadó.

Gacel-Ávila, J. (2009) Joint and Double Degree Programmes in Latin America: Patterns and Trends. The Observatory on Borderless Higher Education.

Halász G. (2013) Az oktatáskutatás globális trendjei. Budapest, ELTE Eötvös Kiadó. http:// halaszg.of.hu/download/Oktataskutatas_MTA.pdf [Letöltve: 2018. 02. 03.]

Kenm, B. M. \& Teichler, U. (2007) Research on Internationalisation in Higher Education. Journal of Studies in International Education, Vol. 11. Nos 3-4. pp. 260-273.

KNight, J. (2003a) Updated Internationalization Definition. International Higher Education, 33. 2-3.

Knight, J. (2003b) GATS, Trade and Higher Education: Perspective 2003 - Where Are We? Toronto, Ontario Institute for the Study of Education, University of Toronto.

Knight, J. (2004) Internationalization Remodelled: Definition, Approaches, and Rationales. Journal of Studies in International Education, Vol. 8. No. 1. pp. 5-31.

Knight, J. (2008) Joint and Double Degree Programmes: Vexing Questions and Issues. The Observatory.

Knight, J. (2011) Doubts and Dilemmas with Double Degree Programs. Globalisation and Internalisation of Higher Education, Vol. 8. No. 2. pp. 297-312. 
Knight, J. (2012) Student Mobility and Internationalization: Trends and Tribulations. Research in Comparative and International Education, Vol. 7. No. 1. pp. 20-33.

Kovács I. V., Taróssy I. \& KovÁcs K. (2015) A felsőoktatás nemzetköziesitése. Kézikönyv a felsöoktatási intézmények nemzetközi vezetöi és koordinátorai számára. Tempus Közalapítvány, Budapest. http://www.tka.hu/docs/palyazatok/a-felsooktatas-nemzetkoziesitese-ckiadvany.pdf [Letöltve: 2018. 01.29.]

Michael, S. O. \& Balraj, L. (2003) Higher Education Institutional Collaborations: An Analysis of Models of Joint Degree Programs. Journal of Higher Education Policy and Management, Vol. 25. No. 2. pp. 131-145.

Nickel, S., Zdebel, T. \& Westerheijden, D. (2009) Joint Degrees in European Higher Education. Gronau/Enschede, Euregio.

Obst, D., Kuder, M. \& Banks, C. (2011) Joint and Double Degree Programs in the Global Context - Repont on an International Survey. New York, Institute of International Education. https://www.iie.org/-/media/Files/Corporate/Publications/Joint-Double-DegreeSurvey-Report-2011.ashx?la=en\&hash=4334DD4FA48CB91A73B7A627256E7BAB94 BA9AA9 [Letöltve: 2018. 01. 17.]

OECD (2004) Internationalisation and Trade in Higher Education: Opportunities and Challenges. Párizs, OECD.

Tempus Közalapítvány (2017) Erasmus Mundus mesterképzések. http://www.tka.hu/ palyazatok/736/erasmus-mundus-kozos-mesterkepzesek [Letöltve: 2018. 04. 14.]

Tнам, S. Y. \& Кам, A. J. Y. (2008) Internationalising Higher Education: Comparing the Challenges of Different Higher Education Institutions in Malaysia. Asia Pacific Journal of Education, Vol. 28. No. 4. pp. 353-367.

VArga B. (2014) Az Erasmus Mundus közös mesterképzések: Jó gyakorlatok az ELTE példáján keresztül. In: ÖRsI G. (ed.) Tudásexport: A felsőoktatás nemzetköziesitésének eszközei. Campus Hungary esettanulmányok 2014. Budapest, Balassi Intézet. http://www. campushungary.hu/rolunk/sajtoszoba/kiadvanyok [Letöltve: 2018. 02. 19.]

Yemini, M. \& SAgie, N. (2016) Research on Internationalisation in Higher Education-Exploratory Analysis. Perspectives: Policy and Practice in Higher Education, Vol. 20. Nos 2-3. pp. 90-98.

Wächter, B. (2008) Internationalisation and the European Higher Education Area. Brüsszel, Academic Cooperation Association. 